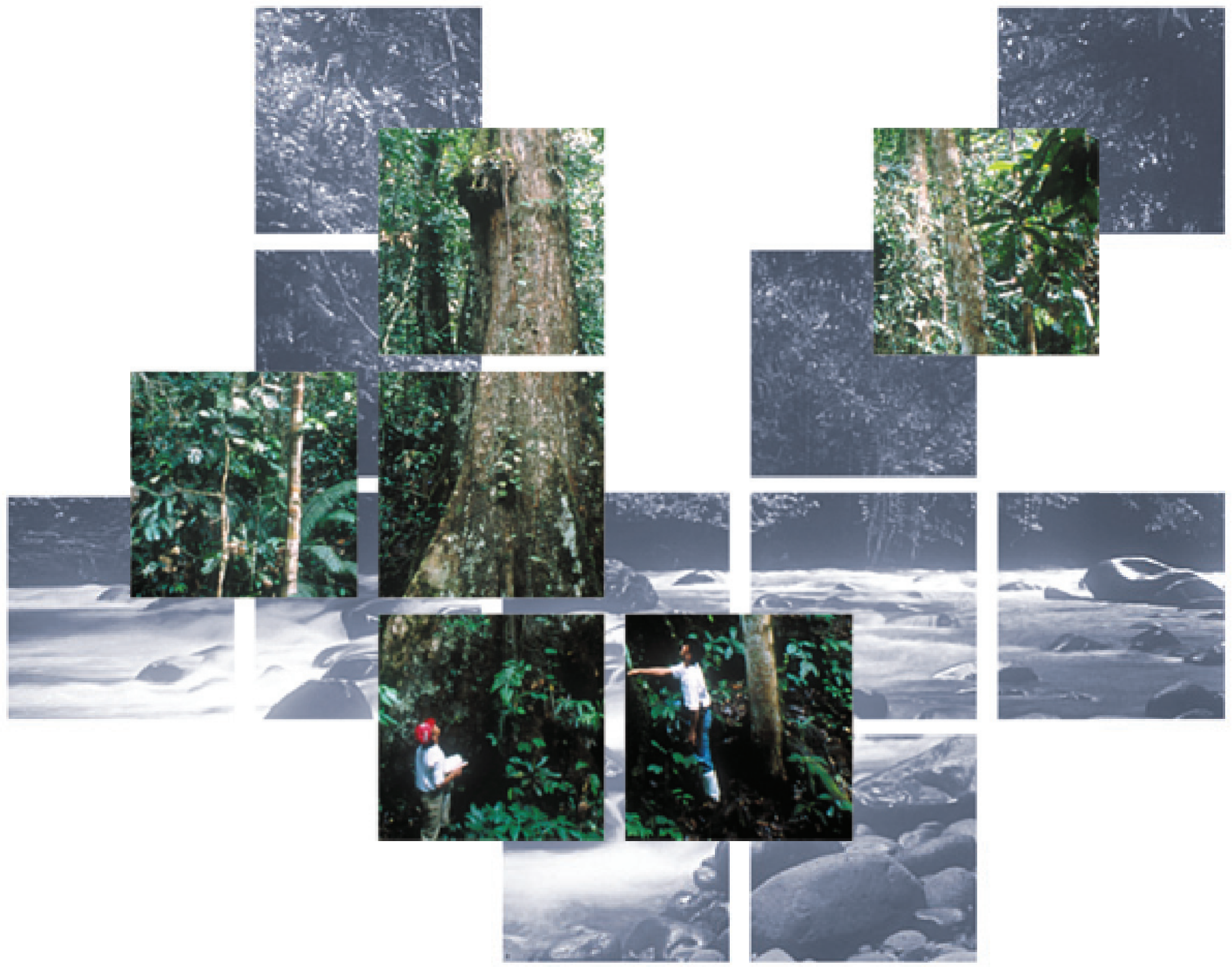

\title{
A Rough Guide to Developing Laws for Regional Forest Management
}

Jason M. Patlis

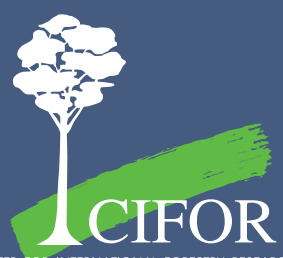




\title{
A Rough Guide to Developing Laws for Regional Forest Management
}

\author{
Jason M. Patlis
}


The author, Jason $\mathbf{M}$. Patlis, is an expert in natural resource law and governance. He has worked on natural resource issues in Indonesia since 2000 , originally as a Fulbright Senior Scholar. Prior to that, he served for almost 10 years with the U.S. government, including from 1997-2000 as Majority Counsel for the Committee on Environment and Natural Resources of the U.S. Senate.

He currently works as Senior Legal Advisor for the USAID-funded Coastal Resources Management Project, where he directs the project's legal reform program in working with regional and national agencies and stakeholders to improve the legal and institutional structures for coastal and natural resource management.

Cover photo by Herwasono Soedjito

(c) 2004 by Center for International Forestry Research

All rights reserved. Published in 2004

Printed by Rediprint

ISBN 979-3361-44-1

Published by

Center for International Forestry Research

Mailing address: P.O. Box 6596 JKPWB, Jakarta 10065, Indonesia

Office address: Jl. CIFOR, Situ Gede, Sindang Barang,

Bogor Barat 16680, Indonesia

Tel : +62 (251) 622622

Fax : +62 (251) 622100

E-mail: cifor@cgiar.org

Web site: http://www.cifor.cgiar.org 


\section{Table of Contents}

Acknowledgements iv

Abstract $\quad \mathrm{V}$

$\begin{array}{ll}\text { I. Introduction } & 1\end{array}$

II. The Existing Legal Framework 3

III. Responsibilities of the Regional Governments 6

IV. The Principles of Developing Regional Forestry Laws 8

V. The Mechanics of Developing Regional Forestry Laws 17

$\begin{array}{ll}\text { VI. Conclusion } & 20\end{array}$

$\begin{array}{ll}\text { References } & 22\end{array}$ 


\section{Acknowledgements}

The author wishes to thank CIFOR, for supporting the research and publication of this guide. Special gratitude goes to the CIFOR team at Long Loreh, Malinau, East Kalimantan, including Godwin Limberg, Njau Anau, Ramses Iwan, and especially I Made Sudana, for their advice, guidance, knowledge, encouragement, and company. Gratitude also goes to the CIFOR staff in Bogor, including Carol Colfer for the initial decision to support research leading to this report, Lini Wollenberg for continual direction, Chris Barr, Moira Moeliono and Tony Djogo. Special thanks goes to Dina Juliarti Hubudin for tirelessly arranging logistical issues.

The author also wishes to acknowledge the people of Malinau with whom the author met, many of whom patiently responded to the author's questions during interviews and informal discussions. Community leaders and individuals include Ipo Kre, Lungu Impang, Markus Impang, Yusuf Incau, Alan Lawing, Aran Alang Phi, Alang Lungu, Ipo Boy, Iran Usat, Martin of Senteban, Armin Argung, Alan Laing, Ingan Ipo, Unyat Iman, Abia of Long Bila. Regional government officials include Pak Khariul, Pak Saparuddin, Pak Moses Gurodaboro, and Pak Iwan Ajang.
The author also wishes to thank other individuals who have assisted him with ideas, advice and inspiration: Wiwiek Awiati, Chip Barber, Chris Bennett, Paul Breitzke, David Brown, Tim Brown, Mario Buccocci, Wahyuningsih Darajati, Ian Dutton, Elfian Effendi, Chip Fay, Sapta Putra Ginting, Koesnadi Hardjasoemantri, Jeff Haywood, Laurel Heydir, Marc Hiller, Azis Khan, Nalin Kishor, Maurice Knight, Owen Lynch, Reed Merrill, Mering Ngo, Nonette Royo, Mas Achmad Santosa, Ann and Bob Seidman, Sulaiman Sembiring, Michael Sinclair, Daud Silalahi, Scott Stanley, Kathleen Surcliffe, Ronald Titahelu, Sukma Violetta, Adi Wiyana.

Funding for research conducted in preparing this report was provided through a Fulbright Senior Scholarship, 2000-2001, and by CIFOR.

Funding for the translation and dissemination of this document was provided by the Program on Forests (PROFOR).

The views expressed in this guide are solely those of the author and do not represent the views of CIFOR.

Jason M. Patlis

June 2004

jason@yourearth.net 


\section{Abstract}

Indonesia has experienced a rapid change in governance since the fall of President Suharto, with a profound shift to regional autonomy and decentralised management that rests primarily with the 420 or so districts (kabupaten) and municipalities (kota) in the country. In exercising this new authority, district/municipal governments maintain significant responsibilities and obligations. Districts/ municipalities have a responsibility to ensure that their laws and policies are consistent with those of the central government. They also have a responsibility to develop laws in the public interest and to follow the principles of what is typically considered 'good governance', in order to ensure that natural resources are sustainably used. While recent legislation often uses broad, general language to refer to the three pillars of good governance-access to information, participation, and justice-there remain few meaningful details on how regional governments are to implement those principles in real-life situations. In addition, there is generally no consistent methodology used in developing new laws.

This paper provides a rough guide for developing regional legislation to manage forestry resources. It first describes the responsibilities of regional governments. Next, it describes some of the more important principles that should be applied in lawmaking and identifies some feasible alternatives to implement them. It then outlines a methodology for developing new legislation. The paper proposes alternatives and methodologies that a district/ municipality with limited experience and limited funding can carry out for meaningful improvement in development of new legislation for forestry management. 


\section{Introduction}

Since the fall of President of Suharto in 1998 and the beginning of the era of reformasi ('reformation'), two trends in the legal system of Indonesia have been prevalent: lawmaking has moved from the central government to the regional governments; and it has moved from the administrative branch to the legislative branch of government. These two trends offer tremendous potential for improvement in the legal framework governing forestry resources. Many studies discuss the benefits of decentralisation in terms of efficiency, transparency, accountability, and responsiveness (Asia Foundation, 2002). A growing body of literature points to decreased corruption associated with decentralised management (Fisman and Gatti, 1999). The same benefits are also felt as laws are developed by democratically elected legislative bodies rather than by appointed administrative personnel. A democratically elected local legislature is likely to be more accountable in its activities than an executive branch with many long-term appointees and civil servants that do not answer directly to voters (ADB, 2002b).

In conjunction with reformasi, regional autonomy (otomomi daerah) was set in motion with a series of laws enacted in 1999, giving regional governments authority to manage forestry resources and to receive revenues from forestry resources. This represented a tremendous change after decades of following legal dictates from the central government. Districts and municipalities throughout Indonesia have responded to this change with a flurry of new laws relating to forestry management, even though many of them have little experience in developing new legislation. The bodies are using their authority in a variety of ways and exercising their autonomy in varying degrees (Simarmata 2003). Some new laws foster meaningful forestry conservation, while others facilitate further degradation.

In addition to new authority, regional governments also have new-found obligations and responsibilities in using this authority. One responsibility is to ensure that laws and policies are consistent with those of the central government. Despite the advent of regional autonomy, central government laws still take precedence over regional laws, especially for natural resource management (Act 22/1999, §10). Regional governments also have a responsibility to develop laws in the public interest and to follow the principles of what is typically considered 'good governance'often defined as three pillars: information (transparency); participation; and access to justice (enforcement) (WRI, 2002).

The benefits and risks of decentralised forestry management will depend on how regional governments interpret and implement their authority and responsibilities. The key to increasing the benefits of decentralisation and improving the legal framework is to enact laws that confront, rather than ignore, the practical realities of society. Specifically, past legislation ignored the realities of corruption and non-compliance and were written as if they would be fully implemented and enforced (ADB, 2002b). New legislation must address such realities. For example, if in the past there has been widespread noncompliance with regulatory measures, it is unrealistic to expect that new regulations may enjoy better compliance. Rather, to encourage desired behaviors new regulations should present alternative measures such as voluntary, incentive-based programs, or recognition of adat systems of governance. ${ }^{1}$ Likewise, if government agencies are neither transparent nor accountable, new regulations may not be faithfully implemented. Rather, new regulations should establish independent auditing agencies or empower non-governmental entities and adat institutions to ensure accountability in decisionmaking. The bottom line is that by using their legislative authorities, regional governments now have opportunities to explore new modalities and new mechanisms to exercise their new responsibilities.

\footnotetext{
${ }^{1}$ Adat translates literally to mean 'customary' or 'traditional.' In the context of governance, the term connotes a customary or traditional or system of laws or behaviors that govern a community independent of state government or positivist rules (ADB, 2002a).
} 
This paper is meant to guide decision-makers first in the decision whether to even undertake a new law, and then, assuming such a decision is made, how to do it. It is important to recognise that in many cases, once decision-makers begin to analyse the issues in developing a new law, they may find that a new law may not be the best course of action. They my find that better implementation of an existing law is a more favorable course of action.

If a new law is in fact the best course of action, this paper provides a rough guide for districts and municipalities to develop legislation. It first describes some of the basic responsibilities of district and municipal governments. Next, it describes some of the more important principles that should be applied in lawmaking and identifies some feasible mechanisms to implement those principles as well as some alternatives that are easy and effective. A district or municipal government should be encouraged to develop additional alternatives that may be better suited to its own circumstances. The alternatives presented in this paper are not the only ones that exist; they are simply examples. In addition, these alternatives should not be considered mutually exclusive of each other; often, several alternatives are best combined. And sometimes alternate mechanisms don't exist. This paper is meant to serve as a point of departure for decision-makers to craft their own decisions that they find most suitable.

While sections of this paper may give the impression that there is only one approach to lawmaking, there is not. Lawmaking is a living, dynamic process that will vary among jurisdictions, among regions, among subjects, and among individual decision-makers. While there certainly are better and worse ways, there is no one right way. Law is more a process than a product. It not only the substance of new laws, but it is the procedure by which those laws are conceived, drafted, socialised, enacted, and finally implemented and enforced. It is an evolution of thought as to how government and civil society interact with one another.

This paper is intended to be used as a guide primarily for regional government officials, representatives of non-government organisations, and other stakeholders, particularly at the regional level. The author hopes that decision-makers will find this report a valuable contribution to their efforts to reform the legal framework at both the central and regional levels in order to more sustainably manage the forests of Indonesia. 


\section{The Existing Legal Framework}

\section{A. Regional autonomy laws}

The Republic of Indonesia has engaged in a significant effort to decentralise authority of the government to the provincial and district/municipal levels. This effort is riding on legal machinery that has moved at a phenomenally rapid pace (Hofman and Kaiser, 2002). In 1999, three laws were enacted by the central government to mobilise the process: Act No. 22/1999 on regional autonomy; Act No. 25/1999 on regional revenue-sharing; and Act No. 28/1999 on corruption, collusion, and nepotism. ${ }^{2}$ Act No. 22/1999 is the primary vehicle for decentralisation. The overall goal of Act No. 22/1999, stated in Article 4, is to authorise local communities to arrange and organise their own affairs, through their own decisions, based on their own aspirations. Article 7(1) provides that this authority covers every governance field except foreign affairs, defense and security, justice, finance, and religion. The central government can, however, retain authority in other areas of governance through regulations. In addition, the central government, pursuant to Article 7(2), retains authority to develop policy regarding a host of subjects including natural resource use and conservation (Bell, 2001). Thus, the role of the central government is primarily one of establishing guidance and standards, rather than direct regulation and control, with specific action to follow at the regional level. Although the central government's role is characterised as one of providing guidance, it still maintains the ability, pursuant to Article 7 of Regulation No. 25, to take administrative action against a regional government that fails to implement existing laws or regulations. ${ }^{3}$

Despite the broad push towards decentralisation, under Act 22/1999, the central government holds the ultimate trump card over the regional governments: it can invalidate any regional regulation that contravenes the public interest or higher regulations (Act No. 22/1999, §114(1)). Regional governments are obligated to submit newly enacted regional regulations to the Ministry of Home Affairs 15 days after enactment for review (Act No. 22/1999, §113). If cancelled by the Minister, the regulation must be withdrawn by the regional government; if the regional government doesn't agree, the issue goes directly to the Supreme Court (Act No. 22/ 1999, §115). This provision has not been widely exercised, although in recent months, as the Ministry of Home Affairs works through a backlog of newly submitted regional regulations, it has invalidated a number or regional regulations that violate basic central government laws, mostly on taxation issues and improper fees for business activities (Simarmata, 2003).

The provinces' role is primarily one of coordination and oversight. Article 9 of Act No. 22/1999 provides that the province retains authority in three circumstances: (1) authority for issues that cross borders between two or more districts/ municipalities; (2) authority not yet, or not able to be, handled by the district/municipality; and (3) administrative authority delegated from central government.

With respect to natural resources, Article 10(1) of Act 22/1999 provides that the regional government is authorised to manage available natural resources in its area, and is responsible for 'maintaining environmental preservation pursuant to law'. This means that although districts and municipalities maintain authority for management of environment and natural resources, they must do so consistent with existing central government laws.

If Act No. $22 / 1999$ is the vehicle for decentralisation, then Act No. 25/1999 is the engine. It provides for an almost complete shift of budgetary management from the central government to the regional government. Act No. 25/1999 provides that the central government gets only 20 percent of natural resource revenues, specifically forestry, fishing, and mining, while the regional governments get 80 percent. Of that share, districts/municipalities receive 64 percent and provinces receive 16 percent

\footnotetext{
2 A note on terminology: 'Act' is used to refer to 'undang-undang' specifically, while 'Regulation' refers to a 'peraturan pemerintah'. It is common to use 'Law' to describe an 'undang-undang', but it is not accurate, as 'law' is a general term translated as 'hukum'.

3 'Regional governments' is a term that includes both district and provincial levels of government.
} 
(Act No. 25/1999, Article 6(5); Regulation No. 104/ 2000 , §§9-10). Of forestry revenues, half of the district/municipalities share is divided equally among all districts, and half goes to the particular district/ municipality in which the activity is taking place. Of the Reforestation Fund, where a certain percent of the income derived from forestry activities is required to be reinvested in resource management and conservation, 40 percent is now required to the regional governments and 60 percent to the central government. Act No. 25/1999 and other regulations have also increased the authority of district governments to levy taxes on activities, goods and persons.

While these four laws-Acts No. 22/1999 and 25/ 1999, and Regulations No. 25/2000 and 104/2000form the core of decentralisation, there are an estimated 1000 other regulations, decrees, and guidelines in the process of being modified to be consistent with those four core laws (GTZ, 2001). And numerous questions remain as to the extent of central and provincial authority, and exactly how that authority is to be exercised in light of the emphasis on district/municipal authority. The major issue now confronting otonomy daerah concerns the development of obligatory functions and minimum standards of service (standar pelayaan minimal, or SPM)-those standards that districts and municipalities must meet regardless of how they exercise their authority. Guidelines providing for those basic functions and minimum standards are required pursuant to Regulation No. 25/2000 (Article 2(4)(b)). Major questions relate to the appropriate scope of these standards, whether they should be mandatory or discretionary, and whether they should be imposed through incentives or sanctions (Donor SMP Working Group, 2002; Patlis et al., 2001). Other questions include the level of detail and consistency of the standards among sectors and regions. Currently, the Ministry of Home Affairs is implementing two decrees that it issued last year that lay out the framework for developing SPMs (Ministry of Home Affairs, 2002a and 2002b).

\section{B. Forestry laws}

The overall legal structure governing forestry resources is shaped by the basic forestry law enacted in 1999, Act No. 41/1999, and its implementing regulation, Regulation No. 34/2002. While these laws supersede the original forestry statute of 1967 and Regulation No. 6/1999, a great deal of uncertainty exists regarding lower legal mandates. Although numerous laws have been enacted under the new statute and regulation, many other legal mandates that predate Act No. 41/1999 and Regulation No. 34/2002 are still in force. As Article 82 of Act 41/1999 states, all existing rules remain in effect insofar as they do not conflict with the Act. This provision underscores the fact that much of the legal framework governing forestry management is residual from the old basic forestry law. Regulation No. 34/2002 exacerbates this ambiguity: Article 100 explicitly repeals Regulation No. 6/1999, but Article 101 states that all other regulations and ministerial decrees implementing Regulation 6/1999 remain in full force and effect insofar as they do not contradict the new regulation, and insofar as they are not amended or repealed by subsequent regulations or decrees. This type of 'implied repeal' creates many ambiguities in legal interpretation. Conflicts in interpretation and implementation are not uncommon and are difficult to resolve.

The conflicts are compounded by the fact that Act No. 41/1999 and Regulation No. 34/2002 are considered to be centrist in nature, even though they were enacted after Act 22/1999 and rely on it as one of its authorities. Act No. 41/1999 states that the central government still maintains responsibility to determine status and classification of forest lands, to inventory and map, and to prepare forest plans. Regulation No. 34/2002 clarifies that only the central government can issue permits for timber harvest, based on the recommendations of the lower levels of government (Regulation No. 34/2002, \$42). This is a significant change from the forestry regulations and decrees of recent years, which have allowed some types and some variations of permits to be issued by regional heads of government. The elucidation to Regulation 34/2002 provides that the Minister may gradually and selectively delegate authority to issue permits for utilisation of wood products in production forests to the regions if the regions demonstrate readiness in terms of institutions, vision or mission, but there are no specific guidelines or conditions for this.

There is very little mention of regional authority over management decisions in Act No. 41/1999. The only references to regional authority come in the context of supervising activities on forest lands. For example, Chapter VII of the Act (Articles 59-64) provides that both central and regional governments are responsible for forest supervision. Chapter VIII (Article 66) states that the central government may delegate certain authorities to regional governmentthose authorities intended to improve efficiency in forest administration. Consequently, what little role exists for regional governments is essentially administrative, with no meaningful decision-making authority given to them. Regulation No. 34/2002 follows this approach although it gives authority to regional governments to issue permits within their jurisdiction for non-timber activities including use of area, use of environmental services, use and collection of non-timber products. 
This centrist position is juxtaposed by recent attempts-virtually all now rescinded-at decentralised forestry management in which the central government authorised regional governments to issue a variety of permits for timber harvest and other activities. For example, Regulation No. 6/1999 (now rescinded) provided authority to the governor to issue Hak Pengusahaan Hutan (HPH) for concessions covering 10,000 hectares or less and for the district head to issue permits for Hak Pemungutan Hasil Hutan $(\mathrm{HPHH})$ for concessions covering 100 hectares or less; both types of permits were for no longer than one year in duration. Those permits were subject to the Provisi Sumber Daya Hutan (PSDH) and, if they concerned wood extraction, the Reforestation Fund. Ministerial Decision 310/1999 (also now rescinded) followed Regulation No. 6/1999 in elaborating that HPHHs of 100 hectares could be issued for conversion forests or production forests that were intended for conversion or reclassification, although it specifically prohibited the issuance of HPHHs for lands that were already under $\mathrm{HPH}$ concessions. Since those laws, district governments have created a host of names for timber extraction permits that have similar terms and conditions but do not necessarily follow the conditions of the laws. Those include IPKs, IPPKs, IPKHs, IPKTMs, IPHHs, HPHKMs, HPHHs, and HPH kecil. To a large extent, the Ministry's earlier efforts at decentralised forestry management opened a Pandora's Box of legal, quasi-legal, and illegal actions on the part of regional governments. As the central government has attempted to recentralise the issuance of permits through new laws, districts and municipalities do not always recognise those new laws and are insisting on exercising permitting authority under the general language of Act No. 22/1999.

Despite these inherent conflicts and the systemic difficulties in interpreting the legal framework governing forestry resources, numerous requirements are clear and unambiguous (Patlis, 2002). For forest planning, the Ministry must first prepare a Consensus Forest Use Plan, or Tata Guna Hutan Kesepakatan (TGHK), for each province followed by a Forest Land-Use Plan, or Rencana Pengukuhan dan Penatagunaan Hutan (RPPH), using forest classifications and boundaries from the TGHK and coordinated with the provincial spatial plan, Rencana Tata Ruang Wilayah Propinsi (RTRWP). Timber concessions must follow an array of procedural, substantive, and financial requirements to obtain their $\mathrm{HPH}$ permits and carry out forestry activities within their concessions. Concessionaires are required to complete numerous reports, of which the two most important are the Laporan Hasil Cruising (LHC), which includes information on tree numbers, species, size, and volume based on on-site inspections of the cutting block, and the Laporan Hasil Produksi (LHP), which includes information on all trees-species, size, volume-actually harvested. With respect to production, a permit for a sawmill or processor with capacity up to 6000 cubic meters per year shall be issued by the Governor, taking into account technical comments from the district and with approval by the Minister (Regulation No. 34/2002, \$64). Operations larger than 6000 cubic meters per year require a permit issued by the Minister, based on comments of the Governor. With respect to transport, all timber products must have a Certificate of Legal Forestry Products (SKSHH) and a Wild Plant and Animal Transportation document (SATS) (Regulation No. 34/2002, §75). Physical condition, size, type, quantity, and destination of the timber products must all match the terms of the documents. It is beyond the scope of this rough guide to spell out the requirements in detail, but district and municipal governments should be familiar with them. 


\section{The Responsibilities of the District/Municipality}

In this era of decentralisation, districts and municipalities have many responsibilities with respect to natural resource management that did not previously exist. First, given the continual changes taking place in development and implementation of new laws at all levels of government, the district and municipal governments must maintain regular contact with their provincial and central government counterparts to keep abreast of new regulations and policies. In addition, by remaining informed, they can better influence the changes that are likely to be made. There are several associations that have recently formed to represent regional government bodies. The Asosiasi Pemerintah Kabupaten Seluruh Indonesia (APKASI) represents the district administrative governments; the Asosiasi Dewan Kabupaten Seluruh Indonesia (ADKASI) represents district legislatures. Municipal governments also have an association for administrative bodies, Asosiasi Pemerintah Kota Seluruh Indonesia (APEKSI), and one for legislative bodies, Asosiasi Dewan Kota Seluruh Indonesia (ADEKSI). For provincial governments there are also two groups, one for the administrative body, Asosiasi Pemerintah Propinsi Seluruh Indonesia (APPSI), and one for the legislative bodies, Asosiasi Dewan Propinsi Seluruh Indonesia (APDSI). Districts and municipalities can also form regional groups that share similar interests from a geographic or sectoral standpoint in order to share information and develop positions.

Second, district and municipal governments must make a dedicated effort to learn the status of existing laws that they now are required to implement. With respect to forestry resources, Article 10(1) of Act 22/ 1999 provides that the regional administration is authorised to manage available natural resources in its area and is responsible for 'maintaining environmental preservation pursuant to law'. This requirement cannot be overstated. Previously existing national environmental laws are still in force under Act No. 22/1999, but now must be implemented by the district and municipality rather than central government. It is therefore the responsibility of the district/municipality to know and understand the requirements of the laws including those relating to natural resources and biodiversity, environmental management, mining, fishing, forestry, water, and requirements for environmental assessments (Analisis Dampak Lingkungan (AMDAL). It is also the responsibility of the district/municipality to implement and enforce those laws.

The lack of basic information at the local level regarding existing laws is underscored by the fact that districts and municipalities are exercising authority without any clear guidance, rationale, and on occasion, without any apparent concern for the law (Simarmata, 2003). For example, over an 11 month period in Malinau, East Kalimantan, two successive district heads issued 39 timber extraction and utilisation permits entitled ljin Pemungutan dan Pemanfaatan (IPPK) totaling almost 56000 hectares for small forestry concessions (Barr et al., 2001). Even though applicable law limited these concessions to 100 hectare allotments, Malinau was issuing permits that covered as many as 5000 hectares of forest. In addition, many IPPKs allowed clear-cutting, which is prohibited under central law; they specifically authorised harvesting of individual endangered species protected under central law; and they did not include required conditions relating to environmental planning, monitoring, and reporting (Mariasa, 2001 personal communication).

Another example of clearly illegal activities by districts is the practice of collecting taxes or retribution on the illegal transport of timber across district jurisdictions. This practice, being carried out in East and Central Kalimantan, is sometimes codified (Casson, 2001), sometimes not (McCarthy, 2001). Districts and municipalities have an obligation to seize as illegal contraband timber that does not have requisite paperwork and markings. In this case however, they do not seize it but rather levy a surcharge on its transport and allow the transport to proceed. In this way, the district openly engages in the legal fiction that the timber is of uncertain, rather than illegal, origin. Taxes such as these are not legal as they allow the transport of illegal timber, which is unauthorised pursuant to central government law. It is important to note that these payments do not 'legalise' the timber-the timber was logged illegally and subsequent compliance with 
regional or central laws does not change that fact. Rather, these payments complicate proof that the timber had been illegally harvested. District and municipal governments must be cognisant of these implications.

Third, district and municipal governments must develop budgetary planning and management skills. Because much of a district's or municipality's new source of income is derived from natural resource use, the revenue distribution will vary enormously from region to region (Brown, 1999). More importantly, most of the income is used for administrative expenditures rather than programmatic or development activities. Thus, the district/municipality will often have very little new revenue to apply development projects and resource conservation, unless the district/municipality begins to collect original revenues in the form of taxes, or in the exploitation of natural resources. There are numerous laws relating to accounting and transparency that have recently been enacted, but these laws alone do not give the district/municipality administrative bodies the capacity to plan and manage budgets.

Fourth, and perhaps most important, district and municipal governments need to develop new skills in legislative drafting. Poor drafting is a common phenomenon in Indonesia. It can be a deliberate action, in order to foster a system of corruption, collusion and nepotism (Korrupsi, Kollusi dan Nepostisme) (ADB, 2002b), or it can be merely circumstantial when governments have no training and no infrastructure for proper legislative drafting (Seidman et al., 2001). While the lack of political will is usually responsible for the deliberate poor drafting of legislation, circumstantial poor drafting is due usually to a lack of resources (although this may also reflect lack of political will to acquire the resources).

Currently, many district governments exercise their authority in a way that accelerates logging activities and exacerbates conflicts among stakeholders, particularly with regard to tenure claims (ITTO 2001). In Sumatra and Kalimantan, district governments have issued permits both within village boundaries, and within lands already under previously granted $\mathrm{HPH}$ concessions. In East Kalimantan, the lack of adequate mapping and inventory of lands exacerbates disputes regarding boundaries of IPPK concessions, HPH concessions, and village and adat communities (CIFOR Long Loreh team 2001, personal communication). Stakeholders have no clear sense of where legal operations can be conducted or who has legitimate authority to operate; it is not clear whose rights are antecedent and whose are subservient. The problems stemming from poor drafting are exacerbated as decentralisation spawns not only new authorities for district governments, but new district governments as well. The number of districts in Indonesia increased by more than 25 percent from 1999 to the present. The new district governments need training and assistance to develop new laws appropriate for their jurisdictions.

Without adequate training and capacity, legislators may exacerbate already existing problems. A new, poorly crafted law can make a bad situation worse if it is confusing, vague, broad, complicated, and unenforceable. District and municipal legislatures are enacting perda in matters of weeks. ${ }^{4}$ For example, last year, District Malinau enacted six perda relating to desa (village) administration and structure, adat, forest use, and retribution for building construction. The perdas were copied almost verbatim from the neighboring District Bulungan and do not account for the unique attributes of the peoples and forests of Malinau. Unlike Bulungan, Malinau is a sparsely populated district with an extremely diverse array of ethnic groups, many of whom are still semi-nomadic Punan. Malinau's forests are also relatively more healthy and pristine (CIFOR Long Loreh team 2001). The fact that the new perdas do not accommodate these characteristics may ultimately exacerbate problems in Malinau of the displacement of certain groups and the rapid issuance of IPPKs, both of which have caused social upheaval, confused boundary delimitations, and diminished the resource base.

In exercising their new authority for resource management, district and municipal governments have a responsibility to develop laws that manage resources sustainably, for generations in the future as well as in the present, and equitably, for all stakeholders and resource users. Numerous recent studies have revealed that using principles of good governance as the basis for national and regional legal frameworks is a significant factor in achieving sustainable natural resource management (Smith and Martin, 2000). Improvement of the legal framework consists of more then proper legislative drafting; it encompasses functions of administration, enforcement, and adjudication. According to the Asian Development Bank, four practices are critical to improve a legal framework: improve the process of preparing legislation by conducting a regulatory impact assessment; establish efficient means for consultations both within and outside the government; strengthen external accountability institutions; and strengthen the capacity of courts to solve administrative problems (ADB, 2002b). The next section discusses those issues in the context of a number of principles relating to the idea of 'good governance.'

\footnotetext{
${ }^{4} \mathrm{~A}$ 'peraturan dearah,' or perda, is a regulation enacted by a regional government (province or district).
} 


\section{The Principles of Developing Regional Forestry Laws}

Even prior to undertaking the development of a new law on forestry management, a regional government must have a clear understanding of its authorities and responsibilities. It also needs to have a clear understanding of the existing legal framework and consider whether a new law is in fact appropriate for the problem at hand.

Some of the regional authorities and responsibilities are prescribed by the central government while others relate to less concrete, but perhaps more meaningful, principles of 'good governance'. Governance is defined as a process of decision-making among stakeholders. Good governance is characterised by a number of attributes that can be incorporated into that process. The United Nations Economic and Social Commission for Asia and the Pacific (UNESCAP) describes good governance as follows:

[Good governance] is participatory, consensus oriented, accountable, transparent, responsive, effective and efficient, equitable and inclusive and follows the rule of law. It assures that corruption is minimised, the views of minorities are taken into account and that the voices of the most vulnerable in society are heard in decisionmaking. It is also responsive to the present and future needs of society. (UNESCAP, 2002)

The literature is replete with identification and descriptions of good governance, and many scholars and advocacy groups distill them into three pillars: information (transparency), participation, and access to justice (enforcement) (WRI, 2002). However, much more goes into a well functioning legal system; it must have coordinated and integrated decisions, budgetary responsibility, clarity, legal certainty balanced with administrative flexibility, scientific validity balanced with socio-economic considerations, etc. However, the literature lacks detail of how these principles can be implemented on the ground (Botchway, 2001). Many experts have begun to identify and explore these principles. The Food and Agricultural Organisation, for example, define six principles for drafting better forestry laws: (1) avoid legislative overreaching; (2) avoid unnecessary or superfluous licensing and approval requirements; (3) enhance provisions for transparency and accountability; (4) enhance role of NGOs; (5) ensure that the drafting of laws is participative; and (6) ensure that the law includes direct enforcement mechanisms (Lindsay, 2002).

The principles of good governance-however they are defined-fit in one of three basic arenas: process; substance; and equity (see Figure 1). Process deals with the mechanics of a law-how a law is made and how it is carried out. The mechanisms include transparency, participation, coordination, integration, accountability, enforceability, clarity, and budgetary sustainability. Substance deals with contents of a law-what the law says and why it exists. The attributes of substance include legal certainty, administrative flexibility, scientific validity, and socio-economic practicality. Equity deals with application of the law-who is affected and how the law is enforced. Applications of equity include access to adjudication, due process, and fair hearings.

Figure 1. Principles for Local Legislative Drafting

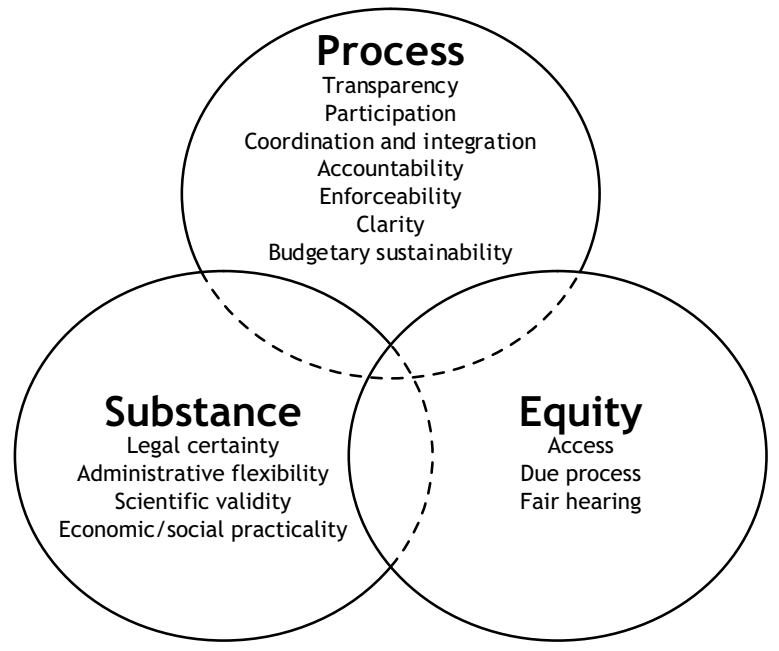

In considering the principles of good governance, two points cannot be overstated. First, the objective of the principles is to create a legal system that is connected to the people it governs-a legal system founded on their needs, desires, and capabilities. It cannot be so normative or aspirational as to be 
unrealistic and unenforceable. Second, the basis of the principles is that the community is involved in developing, knowing, and understanding their legal system to improve implementation, compliance, and enforcement (Lindsay, 2000). In this sense, law is not merely a reflection of the state government or institutional leadership, but rather a reflection of the society at large. As Lindsay (2000) states, recommendation to open up the process of lawmaking "flows [not] only from the belief that people should have the right to be involved; it is a pragmatic recognition that without involvement, there is simply no realistic hope of passing laws that reflect reality and are capable of being used'.

In developing new laws, regional governments must not only include language recognizing the principles of good governance-which they usually do-but they must include concrete, specific language about how to implement those principles. This section discusses some of the principles of good governance and how they might be carried out in a district or municipality with limited resources.

\section{A. Transparency}

A transparent process allows the public to be informed of government decisions that affect them. It also provides an important opportunity for the public to monitor the government to ensure that government decisions are faithful to the lawa check and balance on the government. Transparency requires public knowledge of events, documents, and decisions. And for the public to be informed, it must be notified of every significant step in the decision-making process. For example, in the issuance of a permit or license, the public should be notified of the initial permit application, a draft decision by the government together with data and reports supporting the draft decision, the final decision and any reasons the draft may have been changed, and any subsequent appeals opportunities. Transparency should cause the boundaries between government and nongovernment to become blurred so that information exchange and decision-making involves both groups (Tendler, 1997).

Transparency is not merely a result of knowledge and notification. It requires explanation and discussion. Without discussion, village members may not know the meaning of the decision being made, or the consequences of the decision. District officials must explain the decision if the process is to be transparent. There are several ways to achieve transparency:

Alternative A: Maintain documents and decisions in a public place. This should include copies of all background materials-laws, reports, surveys, economic data, etc.-that may be used in making decisions. A special library or center can be set up in the administrative offices of the district government. This alternative can be easy and inexpensive, but it is unlikely to reach the majority of people, who may not be able to travel long distances to a particular location on a regular basis.

Alternative B: Publish and circulate announcements, documents, and decisions. Announcements can be made in local newspapers, letters, brochures, signs, etc. For example, in many villages, announcements by the camat (sub-district head) and the Bupati (district head) are often posted on the door of the village head, the school, or other public building in the village. Announcements should be made for all significant steps of the decisionmaking process and can also include information about where and how to obtain additional information and documents.

Alternative C: Hold periodic meetings open to the public. Meetings can be held in one place such as the government office responsible for the decision, or in different places such as various villages within the area affected by the decision. This method can be an expensive, but the most effective, means of notification. The meetings should consist of presentations by government officials with opportunity for questions and clarifications afterwards. Meetings must be accessible and publicised in advance if they are to succeed.

Alternative D: Radio broadcasts. This is the most efficient means of notification in districts that are geographically large and sparsely populated, particularly if transportation infrastructure is not well developed. Upfront costs associated with equipment and bandwidth acquisition may be high, but maintenance costs are reasonable, and the access radio provides is constant. The government could maintain a schedule of broadcasts relating to activities and decisions. Sistem Hutan Kemasyarakatan, a nongovernmental organisation based in Samarinda and working in Kutai Barat, has proposed establishing radio links across remote villages for communication and information access.

Alternative E: Individual request and response: This entails the ability of a stakeholder to request specific documents from the government and the obligation of the government to make the document available to the requestor in a timely manner. Responding to individual requests should be used in addition to more public modes of accessing information. 


\section{B. Participation}

Public participation is the next logical step after notification. Once the public is notified of an event relating to a decision, how can it participate in the process to make the decision? Participation allows the public to be involved, creating a more informed public, gaining insight into the decision-making process of the government. Public participation also can lead to a better informed government in that it allows new ideas to be presented to the government, creating a more comprehensive understanding of an issue (Axelrod 1984). It further serves to reduce the likelihood of conflicts in implementing a decision because issues from which conflicts may arise are aired earlier with greater potential of being resolved during the decisionmaking process (Ostrom, 1992). Lastly, it serves as a form of accountability, allowing the public to examine what the government is doing (Estache, 1995).

Numerous definitions of public participation exist, but essentially it comes down to meaningful public involvement in making a decision (WRI, 2002). Involvement can range from merely receiving information to consultation and partnership, and even complete citizen control of the decision-making process (Arnstein, 1969). Various circumstances can determine what level of involvement constitutes 'meaningful,' such as the level of involvement that existed previously; who and what will be affected by the decision; for how long the decision will be in effect; etc. Local laws often require that a process be 'open and democratic', or require 'public participation', but doesn't elaborate what those terms mean. In general, 'notice and comment' entails three things: (1) an opportunity to review draft decisions and supporting materials; (2) an opportunity to comment on those items; and (3) a response from the decision-maker to those comments. 'Notice and comment' requires some forum - face-to-face, or in writing, or some other means of communication - in which the public can submit comments and the government must respond to them in a timely and substantive manner.

However, meaningful participation at the local level requires much more. It requires that government representatives enter the villages affected by a decision, entertain the village assemblies, and engage in a dialogue in which the communities are given access to information. Meetings must be opportunities for community expression, not for government expression. A meeting in which government officials make presentationsoften called 'socialisation'-may suffice to achieve a level of transparency (although even for this, public understanding may require an opportunity for questions and answers), but it does not suffice in achieving any sense of participation. In addition, meetings must be accessible, publicised in advance, and recorded to be meaningful.

Lastly, an ideal form of participation entails negotiations between different interest groups and community members with government agencies. The process would allow formal committees of nongovernment members to develop and negotiate legislative text together with government staff. This can be done on an ad-hoc or permanent basis, with rotating committee membership.

\begin{abstract}
Alternative A: Use notice and comment: Notice and comment procedures can be incorporated into the same alternatives identified for transparency, including announcements, public meetings, and broadcast announcements. Notification would invite the public to respond to draft decisions within a certain period of time. Thirty days for comment is a timeframe often cited as a minimal time for adequate reach (WRI 2002), but this really depends on circumstance. A large district with limited means of communication may require significantly longer. Comments may be written or oral, but minutes must be kept of meetings, and the process must be documented.
\end{abstract}

\begin{abstract}
Alternative B: Establish advisory committees. The government can allow and affirmatively create formal committees or councils of nongovernment members to develop and negotiate legislative text together with government staff. This can be done on an ad-hoc or permanent basis, with rotating membership among different stakeholders. Such committees should not take place in lieu of notice and comment, but in addition to it.
\end{abstract}

\begin{abstract}
Alternative C: Hold public consultations. The government can seek to negotiate policies directly with community members. This process of course, is the most desirable, but is the most difficult to implement. Special meetings may be arranged, however, to negotiate policies and laws with community leaders elected by communities at large.
\end{abstract}

\section{Coordination and Integration}

Coordination and integration relate to the interrelationships within the government and provides for the agency making the decision to involve other agencies and bodies in that decision in a meaningful way. Integration has been the focus of coastal management for three decades (CicinSain 1998), and many lessons can be drawn from those efforts for forestry management. Even within a small district office, communication between 
different departments frequently is lacking. And when it exists, communication is often linear in nature-different departments will review the same documents and sign off on them, but there is no interdepartment collaboration or discussion. Coordination would entail notifying other agencies, as well as giving them an opportunity to participate in the decision-making process. The process of integration further coordinates viewpoints and actions and combines them in ways that are harmonious, resulting in fewer conflicts, fewer redundancies, and ultimately, fewer laws. Many agencies will resist efforts at coordination and integration because they view such efforts as diminishing their authority. In fact, integration does not diminish an agency's authority; rather, it diminishes its autonomy. Effective integration results in a more informed rulemaking process and a more efficient system of governance.

Alternative A: Follow the same procedures for public notification. Other governmental agencies would not be accorded any special role in decision-making, but would participate to the extent that the general public would. No special coordination would be required. Therefore, it can be expected that little improvement in coordination would occur, and agency decisions would continue to be made in isolation of other agencies, which may have knowledge, information, or advice to share.

Alternative B: An agency takes responsibility for coordination. The agency would notify other agencies directly and seek their input directly. While this might present an efficient, costeffective approach to coordination, it can be onerous upon the agency, especially if budget and staff are already strained, as they are in most agencies. In addition, other agencies may not be inclined to assist a sister agency without any mandate. In this alternative, coordination is likely to be only partially successful.

Alternative C: An existing coordinating agency or other interagency body takes responsibility for coordination. Each level of government already has several offices or agencies responsible for coordinating different policies. For example, at the national level, the National Development Planning Agency (BAPPENAS), the Coordinating Secretary for Economic and Social Affairs, and the Cabinet Secretariat's office all have responsibilities to coordinate policies. At the regional level, there is BAPPEDA or the Provincial Environmental Impact Management Agency (BAPEDALDA) specifically for environmental issues. The advantage of this alternative is that it relies on existing infrastructure, which will minimise costs. However, the existing agencies already have biases and positions on many subjects, which may impede opportunity of true reform. In addition, an existing agency may have to be amended to some extent to address the needs of coordinating forestry policy.

Alternative D: A new coordinating agency or other interagency body takes responsibility for coordination. A new coordinating body can be established to oversee coordination. The advantage of a new body is that it would not rely on existing political arrangements, and it can be tailored exactly to the needs of forestry policy. The disadvantage is it can be politically difficult and costly to establish a new agency. Costs may be minimised, however, if an existing agency such as the Dinas Kehutanan (Provincial Forestry Service) provided staff and operational costs. In establishing a new body, many questions need to be addressed such as: should the body be advisory or have decision-making authority; should its membership include only government members, or non-government members as well; how should membership be determined; what should be the scope of its responsibilities; how often should the agency meet; and what should be its rules of procedures.

\section{Accountability}

Accountability is perhaps the single principle most often advocated for good governance. One expert describes it as 'the cornerstone of good governance'. (Bennett, 2001). There are many types of accountability, and different scholars will classify these types differently. One legal scholar observes that "[a]ccountability itself is such a complex concept, with many different definitions in different contexts and according to different political theories, that it makes little sense to address it apart from specific factual situations[; i]t can stand for democracy, legitimacy, control, responsiveness, and and many other attributes of an ideal government or governance structure" (Slaughter, 2001).

For example, one academic school classifies accountability into three types: political accountability, in which a government office or individual is accountable to an elected official, a legislative body, a voting public, or a similar manifestation of civil society that is served by the government; organizational accountability, in which a government office or individual is accountable to a hierarchy within the organization, or to another agency within the bureaucracy; and legal accountability, in which a government office or 
individual is accountable to a series of laws or regulations that govern their actions (ELI, 2003). Another school refers to two types of accountability: horizontal accountability, in which there is a delegation of responsibility to separate agencies; and vertical accountability (or social accountability), in which there is a direct engagement by representatives of civil society (Reuben, 2003). Accountability exists on two levels: institutional and personal. On one hand, government officials make decisions on behalf of their agency and that agency is accountable. On the other hand, those officials also are acting under their own obligations to uphold their responsibilities and to obey the law. They are accountable as individuals (Turner and Hulme, 1997), and may face the prospect of sanctions or penalties by prosecutors or enforcement agencies if they violate those responsibilities.

This discussion focuses on institutional or administrative accountability: how can a law govern the administration of a government or public function to ensure that it is consistent with law (Pope, 2000). (It should be noted, however, that the lack of personal accountability is perhaps a greater problem in Indonesia). Administrative accountability at the regional level is essential to address the rampant corruption and largess that exists in the overall Indonesian government. However, it is also essential to address the more innocent, but equally significant, problem of making decisions with a lack of adequate knowledge of the law and facts.

Governance at the regional level too often is a function of word-of-mouth authority, i.e., authority that is quoted by a government official as being decisive, but for which no formal document-law, regulation or decision-can be found to support it. In addition, because local decisions often involve not only the district government, but also regional offices of the province and central governments, no one office generally assumes responsibility for the overall decision. For example, IPPK permits signed by the Bupati of Malinau are based on size and species estimates determined by the branch office of the Forestry Ministry and the Bupati's office refuses to take responsibility for errors (Gurodaboro personal communication 2001).

Administrative accountability requires four components: (1) a formal decision; (2) a single entity-an agency head or government head-who assumes responsibility for that decision; (3) an opportunity to have that decision examined, reconsidered, appealed; and (4) based on the examination or appeal, there must be the ability to modify or revoke the decision. These four components are based on the fundamentals of administrative law (Aman and Mayton, 2001). Actions must be supported by a formal decision that states the authority forming the basis of that decision; decisions must be made in a timely manner; they should not be arbitrary or capricious in nature.

A discussion of how to achieve accountability could fill volumes. The alternatives listed below focus on the process for review and revision of government decisions. They seek to incorporate the many aspects of accountability discussed above, including horizontal, vertical, political, organizational and legal aspects. First, a word on standard of review: there can be many standards of review for a decision, such as whether it is unlawful, whether it is arbitrary and capricious, whether it is supported by a preponderance of the evidence, etc. In a firstgeneration law, there should be two very simple standards: a standard of legality-that the decision complies with all applicable laws-and a standard of factual basis-that the decision is reasonably supported by all available facts (whether or not the agency knew those facts at the time of the decision).

Alternative A: Administrative review: Administrative review involves the ability to review a decision by an administrative body, i.e., a body in the executive branch of government such as the Bupati's office. Ideally, the process consists of at least two levels: one review by the agency or department that made the original decision; and another review by a higher, independent authority that is not associated with the original decision. It could be a group that reports directly to the Bupati or perhaps even a body of the provincial government. Only with a higher, independent authority can there be any chance for objective, disinterested evaluation of the decision. The advantage to this alternative, compared to judicial review, is that is can be more flexible and faster. More important, it works within a branch of government more familiar to communities.

Alternative B: Judicial review: Judicial review is the typical form of review, but it is rarely utilised and often characterised by corruption. For judicial review to be a viable alternative, the government must seek to provide equal access to communities, which means significant outreach, free representation, and simplified processes for court action. Some nongovernment groups and donor agency projects have begun efforts to reform the judiciary, but early indications are that communities still have an extremely poor understanding of judicial action (Ipo Kre personal communication 2001).

Alternative C: Legislative review: The legislature can itself create a mechanism for review of decisions under a law. It can do this through oversight hearings and investigations 
within its power. Under Articles 18 and 19 of Law No. 22/1999, the regional legislature (DPRD) has significant authority in addressing administrative matters and conducting oversight. The DPRD can thus take a much more active role in ensuring accountability than it has in the past.

Alternative D: Creation of an independent council or agency. A law can create institutions within the government-independent, autonomous bodies-that are responsible for oversight, review and discipline of government agencies and civil servants. Although still part of the government machinery, independent agencies can be more critical of other agencies and even the head of the government. The key to the effectiveness of independent councils is that their members are appointed to fixed terms and cannot be removed at the discretion of other agencies.

\begin{abstract}
Alternative E: Creation of community watchdog groups or other village associations. The law can create a non-governmental entity to monitor and conduct oversight on government agencies implementing a law. This can be in the form of community groups (LSMs or Lembaga Swadaya Masyarakat) and businesses. It can also be in the form of an association of villages, with authority to bring petitions and seek judgments of grievances (Bennett, 2001). Indeed, groups already are forming for enforcement of laws on the national level such as the Association of Commentators on the Police (Gabungan Pengamat Polisi- Gamatpol)). Such groups can form at the regional levels as well. Ideally, legislation should require that government agencies respond to comments and claims made by these watchdog groups.
\end{abstract}

\section{E. Clarity}

It seems self-evident that clarity is a prerequisite for compliance. If a society is to comply with a law, in addition to being accepted by the community, it must be clear and understandable (Seidman, 2001; Botchway, 2001). Even the most compliant community cannot follow a law that is not clear and unambiguous. With clarity, people will know in advance what obligations they must meet.

Clarity comes down to how the law is written and how it is publicised. All too often, legal writing is enshrouded in jargon, obfuscation, and ambiguity. Sometimes this is intentional, but more often, it is just a case of poor writing. While there may not be alternatives to good writing skills, there are alternatives to clarify the laws through supplemental information.
Alternative A: Legislative explanations. This is already a staple in Indonesian legislative drafting. Following almost every law at the national and regional levels is an explanation, or penjalasan, a form of legislative history that elaborates upon the meaning of particular sections of the law. Regional laws would do well to include penjalasan more regularly. In addition, the explanations need to be written more clearly. Often they are written hastily after much of the law has already been drafted and is ready for enactment. Little time or attention is devoted to careful explanations of ambiguous provisions. Instead, explanations should be written concurrently with the actual drafting of the law.

Alternative B: Public explanations and bulletins. The government head, such as the Bupati or Governor, can issue a document accompanying the law that provides an overview of the law and its requirements that is simpler and more comprehensive than the legislative explanation. Bulletins on progress in implementing a law can also be kept and circulated on a regular basis.

Alternative C: Public meetings. Public meetings currently serve the function of 'socialisation', which is essentially a form of explanation of what the law will do. They usually take place prior to enactment as a substitute for consultation. The proper role for socialisation comes after enactment of the law, as a supplemental form of communication. Meetings can take place in a combination of venues to reach those communities most affected by the law, taking into account budgetary constraints.

Alternative D: Radio/DVD recordings. In addition to the use of radio broadcasts as discussed above, explanations can be made on digital video disks (DVDs). Without access to television and radio in remote areas, communities often rely on DVD players for entertainment. Preparation and circulation of DVDs discussing public policy issues can be an extremely cheap and efficient means to convey laws to communities.

\section{F. Scientific validity and socio-economic considerations}

Any law relating to management of natural resources must be based on sound science if it is to be considered a good law that effectively and sustainably manages resources. Scientists may often agree on basic elements of sound science-ecosystem-based management, adaptive management, peer review, 
monitoring and evaluation, etc. -but local governments and managers often do not know those elements or how to implement them. In addition, it is universally agreed that if efforts to conserve natural resources are to be successful, then they must address economic and social aspects surrounding the resources and the people using them (Borrini-Feyerabend, 1997).

The key question is how can local governments connect with the larger scientific and academic communities in improving the scientific validity and socio-economic assessment of their decisions? The basic answer is that there must be a requirement for scientific and socio-economic review of the law. This can be a special process or it can be folded into the public participation process. In either case, there must be adequate opportunity for review and input by the academic experts.

Alternative A: Professional scientific team on staff. If the regional government has staff with adequate expertise, then the scientific review of new laws and activities can be done internally. There should be a public record created to demonstrate that the review was completed.

Alternative B: Community team. If the regional government does not have adequate personnel, or even if it does but would like outside assistance, a formal community team can be established that will review and make recommendations to the district.

Alternative C: Government guidance. If the provincial or central government agencies have greater expertise, they can prepare and publish guidance documents to help district governments make scientifically sound decisions. The utility of such documents is limited, however. Guidance documents are often generic in nature, without adequate details on how to make decisions. Without specific, hands-on instruction, local government officials may not be able to use the guidance documents effectively.

Alternative D: Ad-hoc review. An ad-hoc review would require the regional government to convene a team on a short-term basis for a particular decision. In this way, the government will get the benefit of expert input on a decision without the cost or commitment of having a fulltime staff. The provincial or central government agencies can be responsible for engaging such a team to make rounds among different districts, or an ad-hoc team can be assembled through non-governmental organisations (NGOs) or other agencies on a case-by-case basis.
Alternative E: Long distance review. An adequate dialogue and review by scientists can take place via remote contact using radio, fax, telephone, and the internet. While it may present some logistical challenges, remote contact can provide a low-cost, efficient means to a scientific analysis when there are no scientists available locally. In advance of the review, a local team may gather the data for analysis in preparation for the long-distance review.

\section{G. Budgetary sustainability}

Budgetary sustainability ensures that adequate funding is available to implement the law. In most regional governments, almost the entire budget goes to operations and administration-salaries, pensions, office expenses, etc. Very little is allotted for programmatic costs and development unless a specific revenue source exists. This lack of financial capacity is one of the primary reasons for the profound lack of law enforcement in Indonesia (ADB, 2002b).

Act No. 25 provides funding relating to forestry resources directly to regional governments. As a result, several options for funding new programs are available.

Alternative A: Establishment of a regional reforestation fund. Just as the central government has a reforestation fund, each kabupaten (district) or province can establish one for its own forestry conservation programs. Specifically, a certain percent of the income derived from forestry activities would be required to be reinvested in resource management and conservation. The advantage of this approach is that it secures a dedicated funding source for conservation derived from the groups benefiting from the resource consumption, following the user-pays principle.

Alternative B: Dedicated funding from the general budget. If for whatever reason, a regional government does not wish to fund forestry conservation programs from user fees associated with logging, it can do so with funding from the general budget. This would essentially imply that the communities acrossthe-board share the cost of forestry management, not only the users.

Alternative C: Annual budgetary commitments. This alternative would not seek to secure dedicated funding from any source. Rather, it would rely on specific line-item requests for funding forestry conservation in each annual budget. This approach does not guarantee any specific funding from year-to-year. 


\section{H. Legal certainty}

Legal certainty is at the heart of good governance and rule of law. It is required as a matter of both process and substance. For example, communities need to know how laws are developed - which laws apply when, which laws supercede others, etc. They also need to know how laws are implemented-what the law means, which criteria govern actions, etc. Certainty is essential for an efficient and equitable system of governance.

Economic planning and investment require certainty. For example, the Governor of East Kalimantan recently enacted Law No. 20/2000, which requires timber companies to retroactively pay 1500 rupiah per cubic meter of timber to communities on whose lands the timber was cut. Attempting to collect these fees from companies no longer present or engaged in other activities has created a great deal of confusion. Retroactive laws do not create an atmosphere of legal certainty. Environmental conservation also requires legal certainty. For example, HPH holders who had previously followed central government rules on selective logging no longer have an incentive to do so when the local government has issued IPPKs allowing clear-cutting on their HPH lands. Communities that have no certainty over their land tenure have no interest to conserve that land in a long-term manner (Lynch, 2001; Smith and Martin, 2000).

Social equity also requires legal certainty. For example, communities with limited resources do not have the means to continually influence and follow a changing legal system. Special interests and money politics often drive legislative changes rapidly and without warning towards their own purposes. A legal system that is based on certainty will not succumb to such changes so easily.

Legal certainty must be balanced with flexibilityone quality will benefit at the other's expense. Whether a regional government chooses to emphasise certainty over flexibility should be based on the particular circumstances and issues being addressed. Alternatives look at both aspects of law development (process) and law implementation (substance):

\section{Certainty in legislative development}

Alternative A: Include expiration date in the law. This alternative entails writing a law with a sunset date, or a date of expiration. By doing so recognises that a law needs to change over time and sets a calendar for making such changes. Then all stakeholders know when a law will be considered for revision, and they will be able to plan accordingly. The advantage of a sunset date is that it forces consideration of revisions to improve the law; the disadvantage is that it requires the legislative process to be repeated periodically, which can consume significant time and effort.

Alternative B: Include review periods in the law. The rational for review periods are similar to those of an expiration date. But this alternative doesn't actually allow the law to expire; it provides for a specific time for reviewing the law and considering changes. The disadvantage is that there is no requirement that the law will actually be amended even if a review recommends it.

Alternative C: Enact an umbrella, or framework, law that governs lawmaking process. Establishing a framework law creates a single process for evaluating, reviewing, and amending other laws. It can provide criteria for when laws can be reviewed, and how they can be amended. It also can establish the basic coordinating mechanisms for making decisions either at the legislative or administrative levels of government.

Alternative D: Eliminate the use of 'implied repeals'. Any new law will have some bearing on a prior law-it might supercede it, modify it, or amend it. The standard convention in Indonesian law is to state that all existing laws remain in full force and effect unless otherwise contradicted by the new law. This formulation is an 'implied repeal' and makes statutory interpretation exceedingly difficult as there is no good guidance as to what is contradictory and what is not. Regional governments should take greater measure to ensure that implied repeals are used in only narrow, limited circumstances.

\section{Certainty in legislative implementation}

Alternative A: Establish requirements for activities directly in the law. Most laws in Indonesia, at all levels, provide only very broad criteria guidelines, leaving implementation primarily in the hands of the executive branch. As a result implementation is inconsistent as leaders of the executive branch change or as their political needs change. Rather than leaving details of implementation to the executive branch, the law itself should spell them out.

Alternative B: Include greater detail for administrative decisions. Even if the executive branch establishes most of the requirements through its decisions, there is room in the law for more details on how those decisions should be made. 
Figure 2. Creating a Legal Framework

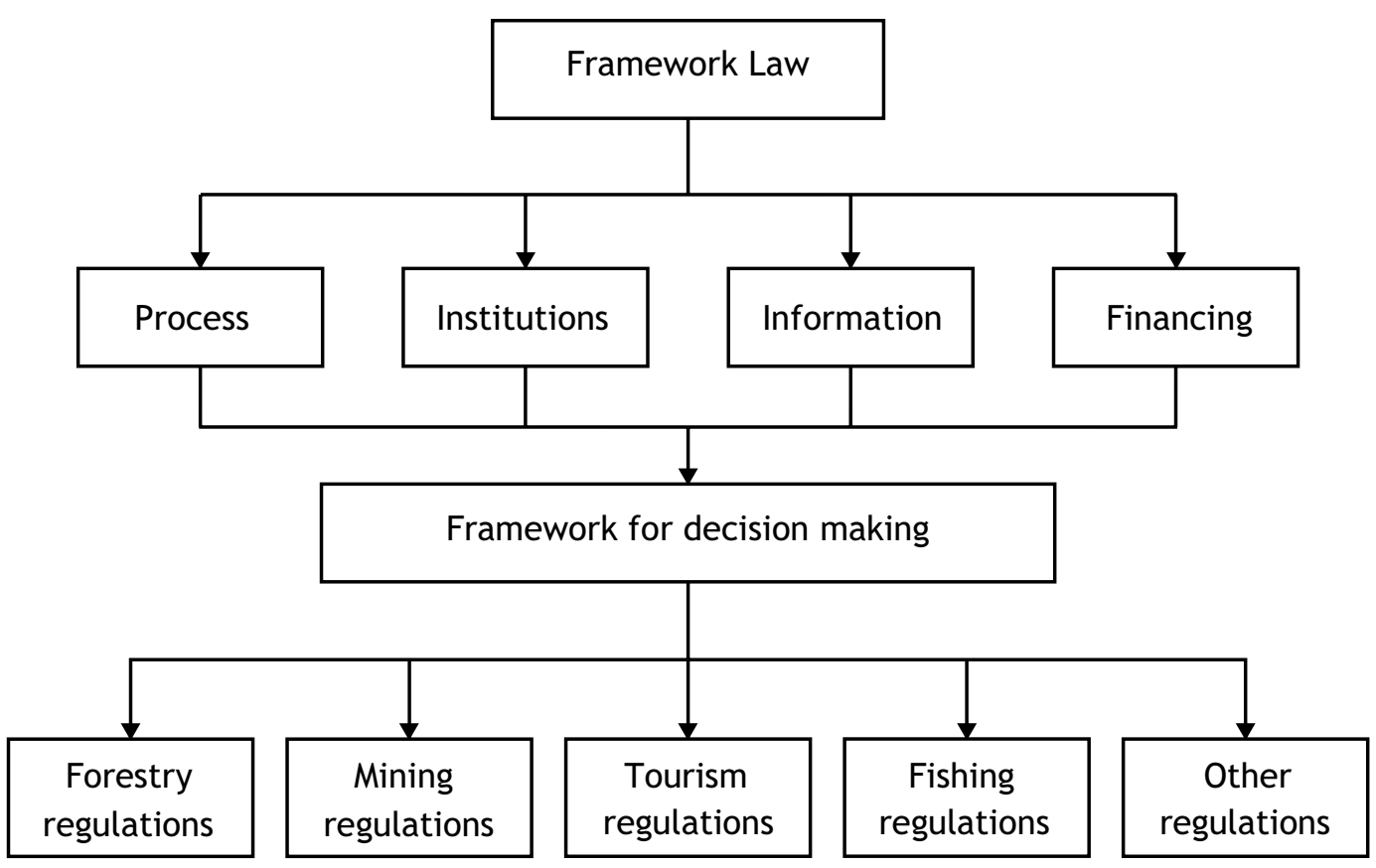

Alternative C: Designate a chain of authority for administrative decisions. Often, legal certainty suffers only because no one knows who is responsible for implementing decisions once a decision is made. Each law should specify roles for the legislature, the Bupati, the Camat, and in cases involving adat, the adat leaders and assemblies.

\section{Administrative flexibility}

Flexibility often comes in the form of discretion. Discretion, in turn, can be used by a government body in either positive or negative ways. On one hand, some discretion is essential in a law because no law can effectively predict all activities or facts that will need to be addressed (Botchway, 2001). On the other hand, too much discretion can lead to arbitrariness, corruption, and unpredictability. Unlike legal certainty, which needs to be affirmatively written into a law, discretion can be either explicit or implicit. For example, if a law is silent on an issue, the presumption is that the implementing agency has discretion to act as it desires on that issue. That discretion is broad and strong and can quickly lead to arbitrary decision making. If a law contains some standards or criteria, as another example, or allows the Bupati to make a final decision, the discretion is more limited.

Limited discretion serves several purposes. First, it allows for a more appropriate, just and equitable application of a law to individual circumstances. Application of a law the in the same way in all circumstances can be unjust and inefficient. Second, it fills gaps in the law. Laws cannot anticipate every possible action or situation. Discretion can be used to apply one law to different situations in different ways. Third, it promotes efficiency in the legal system. Rather than creating new laws-a time-consuming, difficult process-to address a multitude of situations, discretion can be used with the laws that already exist.

Alternative A: Allow for details to be decided in a District or Gubernatorial Decree (Keputusan Bupati or Keputusan Gubernor) or other administrative decision. This practice is already very common in Indonesia and has been the basis for lawmaking for many years. Generally, a law will leave details to be determined in an administrative decision. However, the law often says no more than that. The law can instead include some basic details or subjects that must be addressed in the administrative decision. It can also include the processes that the regional government must follow in issuing a decision to ensure that the principles of good governance are followed not just at the legislative level, but also at the administrative level.

Alternative B: Include standards and criteria in the law for administrative decisions. This alternative allows the Bupati or Governor to make individual decisions within a set of parameters or criteria. For example, permits are issued by the Bupati or Governor. However, the permits should be issued consistent with criteria and standards that are included in the law, and there should be documentation supporting that decision. 


\section{The Mechanics of Developing Regional Forestry Laws}

\section{A. The General Process}

Once a regional government attains an understanding of the basic principles that go into lawmaking, it must then begin to develop a conceptual framework and engage in the process of lawmaking. Lawmaking can be viewed as nothing more than an exercise in rational problem-solving (Seidman et al., 2001). As with solving any problem, the first step is to identify the problem; the next step is to identify and analyse potential solutions to address the problem. Only if it is decided that a new law is best solution, then one can follow the steps for developing a new law.

The Organisation for Economic Cooperation and Development (OECD) offers a checklist of 10 questions that a government needs to answer in developing new laws.

1. Is the problem correctly defined?

2. Is the government action justified?

3 . Is regulation the best form of government action?

4. Is there legal basis for the action?

5. What is the appropriate level of government for this action?

6. Do the benefits of regulation justify the costs?

7. Is the distribution of effects across society transparent?

8. Is the regulation clear, consistent, comprehensible, and accessible to users?

9. Have all interested parties had the opportunity to present their views?

10. How will compliance be achieved?

All but the last three questions need to be answered before the legislation is even drafted-they should be addressed in the scoping analysis and needs assessment and discussed in the research report. A plan for answering the final three questions should also be in the research report.

In general, development of a new law should consist of the following seven steps.

1. Needs assessment/Problem identification. An assessment seeks to define, specify, and prioritise the problems in forestry management that affect all stakeholders. Different stakeholders will face different problems: concessionaires will be concerned with regulatory burdens and economic costs associated with compliance; communities will be concerned with tenure and use rights; NGOs will be concerned with conservation and sustainability. This also entails a determination of priorities and feasibility such as determining what type and scope of legislation is most urgent, and what can be most efficient.

2. Identification of the legal baseline. An analysis of the legal infrastructure and capability of the regional government is the second step. This includes an inventory of existing laws and an evaluation of the legal sophistication of government staff. It also entails an analysis of current implementation and enforcement of existing laws. Frequently, problems may be addressed not through creation of new law, but by enforcement of existing law. Understanding the current legal baseline is the first step to developing a new legal framework. An assessment would be made of the need and desire for additional legislation.

3. Preparation of research report. A formal report is prepared that summarises the needs assessment and legal baseline and lays the foundation for drafting the new legislation. It specifically discusses reasons for developing new legislation, the goals of the new legislation, the scope and content of the new legislation, as well as the process that will be undertaken to develop it. A core drafting team responsible for preparing the report should consist of government and non-government experts and should be aided in its effort by advisory bodies or consultative teams. There must be public participation and active involvement by communities and the public in the preparation of this report; in other words, the report's preparation must abide by the same principles that the preparation of the law itself would follow.

4. Drafting of legislation. The legislative drafting process entails a number of sub-steps. First, a working group convenes to oversee the drafting process. This group should not be large, but the exact number of 
members can vary. This group is chosen primarily from regional government officials as well as academics, LSM and community representatives. Stakeholder groups, consultative groups, or advisory groups can all provide additional comments to the working group. The group works with the research report to first develop an outline and basic framework of the draft law. Next, the content of the law would be elaborated through a series of drafting sessions held by the working group. It is important that both legislative and administrative government officials are involved from the beginning of the process. The common tradition is that legislation is developed either through a legislative process or an executive process, with little involvement by the other branch of government until the final stages. This tradition complicates and hampers the legislative process. The connection between the two branches of government is very strong: one legislates and the other implements. They must therefore coordinate policies from the beginning.

5. Public review of draft legislation. The consultation process aims for a two-way flow of information: the lawmaker must inform the public of its proposed action with the reasons, justifications, and consequences of the action; at the same time, the public must inform the decision maker of its comments and concerns. Thus, both parties have responsibility. Public review can take place in several different stages. First would be public dissemination of the draft law to villages and communities within the district or province. Next would be a series of meetings open to the public to be held among various villages. In addition, a separate series of stakeholder meetings should be held among government officials at the provincial and central levels and include government officials from adjacent districts, non-government representatives from both conservation and industry groups, and academics.

6. Revision of draft legislation. Based on the public review, the draft law is revised. As part of this process, the working group should analyse the comments received and prepare a separate report that summarises the comments and provides responses. The responses should state how the draft law is being altered in response to comments and provide reasons for any changes. It also should explain reasons for not changing the draft law if that is the case.

7. Enactment of the draft legislation. The draft legislation is debated and considered for enactment within the DPRD. Enactment is the final step in developing a new law, but it is also the first step in implementing a new law. One of the most important aspects of successful implementation is the transitional period of a new law. A new law should not necessarily take effect immediately upon enactment; rather, it should have a delayed implementation so that adequate preparations can be made, including public awareness of the new requirements and training and education of implementing agencies and enforcement personnel.

\section{B. The Concept of Framework Legislation}

While legislation will be designed for each circumstance, there are several general models that a regional government can follow. A regional government can begin immediately developing laws on specific topics or sectors, with detailed prescriptions for each sector; or it can begin by developing a set of general, administrative laws that establish an institutional framework for subsequent sectoral laws. This paper recommends, as a general matter, the latter approach.

It makes sense to start with a basic law that serves as a foundation, or framework, for other laws. A framework law will deal with the basic goals, principles, processes, and standards of an area of governance-such as forestry. The framework will lay down the basic mechanisms for governance: setting an agenda for action; coordination; establishing necessary institutions; ensuring necessary funding; and perhaps tackling some basic substantive elements such as education and outreach. It may set up processes for information access and distribution such as a Freedom of Information Act, or it may establish the mechanics for administrative review and accountability such as an Administrative Procedure Act (Andreen, 2000). Specifically, effective framework legislation would accomplish several objectives: (1) establish an agenda for natural resource management including the goals, the vision, and the priorities for actions to conserve and manage resources; (2) delineate the roles and responsibilities of institutions engaged in natural resource management (which may include creating or modifying governmental and non-governmental bodies); (3) establish the informational needs for future management initiatives; (4) secure funding sources for natural resource management; and (5) to the extent possible or practical, establish some programs and activities to fulfill the management agenda.

What is not included in a framework law is equally important: it doesn't attempt to manage activities in which there is only limited experience or knowledge-such management is left for subsequent laws. In a district where capacity is weak or 
experience is thin, the district will not be able to adequately write a new law that is highly detailed and technical. Even if it succeeds in writing such a law (often with outside help through a donor agency project or international non-government organisation), a regional government may not have the ability to adequately implement or enforce the law. A framework law is a means to build capacity in gradual steps. One can look at law development in terms of generations: 'first generation' laws establish the regulatory framework, to be followed by 'second generation' laws that establish the actual regulations.

As a political matter, a framework law has additional benefits. Because it doesn't attempt to overreach in regulating stakeholders, it does not alienate stakeholders, which would only create friction and dilute the usefulness of the law. Rather, it serves to build a constituency around a particular issue, such as the need to better manage natural resources for all stakeholders. Difficult political issues, such as specific regulations, can be tackled subsequently, after a political base and an educated civil society is established.

\section{Voluntary and Mandatory Legal Frameworks}

Law is a tool to shape behavioral patterns. It can act in one of two ways: it can either encourage certain behavioral patterns, or it can simply mandate those behavioral patterns. A prescriptive rule is generally mandatory in nature, and it requires a reasonably strong state apparatus to implement and enforce it. In comparison, a descriptive rule reflects the existing behavioral patterns of society, and would not serve to change behavior; therefore, it would not require a strong state apparatus.

The typical law is one that entails a number of mandatory prescriptions that must be obeyed by regulated community. Mandatory regimes, by nature, are impositions of the will of the governing body upon a segment of society (Hart 1961). They may or may not reflect the will of that segment of society; they may or may not reflect the capabilities of that segment of society. Enforcement of such regimes is critical to their success, which generally requires a significant amount of investment in resources-personnel, funding, and training-that the governing body might not have. If the law reflects the will of society, or if the governing body can maintain a strong enforcement presence, then the law will succeed. However, if the law does not reflect the will of society, or if the law does not reflect the capability of society, and there is little enforcement presence, the law will fail. In many instances, it is this latter scenario-lack of enforcement-that prevails. Consequently, mandatory regimes that appear strong on paper often are weak and ignored in actuality.

Another type of law is one based on incentives, which seeks to encourage behavioral patterns without mandating them. Such a 'voluntary' law does not require the same type of state apparatus that a mandatory regime entails. At the same time, such laws are often relatively ineffectual, because the incentives for maintaining the status quo are often much higher than any incentives to follow a new program.

The optimal approach combines both types of rules: something based on descriptive behavioral patterns but moves toward desired prescriptions. This type of law can built on a voluntary, incentivebased model. The incentives would come with strings attached- local governments would be required to develop laws and programs in accordance with certain standards and guidelines to ensure that they follow good practices. Such a law avoids the unrealistic expectations that so often accompany a prescriptive, mandatory law based on prohibitions and requirements, with little likelihood of enforcement. An incentive-based law can nudge behavioral patterns in a particular direction without necessarily forcing those behavioral patterns. Indeed, there are inherent limitations in such a voluntary, incentive-based program. Behavior may not change since change is not required. However, the approach holds more promise than a mandatory regime that is not carried out at all. 


\section{Conclusion}

Forestry management and governance in Indonesia have undergone rapid and profound changes since 1998, primarily in a shift of authority from central government to regional governments and a shift from administrative lawmaking to legislative lawmaking. In addition, regional autonomy has spawned many new districts across the country. The result is that new bodies of government, primarily regional legislative bodies, have significant new opportunities and responsibilities in managing forestry resources. However, many new regional governments currently lack experience, staff, skills, funding, and other resources to develop and implement new legislation that will promote sustainable forestry management.

Two aspects of new legislation are vital for sustainable forestry management: the principles that go into new laws; and the mechanics of drafting new laws. Scholars and practitioners have identified a number of principles relating to governance of forestry resources in order to achieve sustainability of those resources. While many principles focus on access and participation, information and justice, other critical principles are also necessary to achieve sustainability-principles that relate to, among other issues, coordination and integration, accountability, legal certainty, clarity, and administrative flexibility. These principles of good governance can be grouped into three themes: process (how a law is made); substance (what a law says); and equity (how a law is implemented). However, relatively few examples exist of how these principles can be applied in practice, especially at the local level by governments with limited means. Regional legislation may recognise some of the principles in broad, general language, but without specific language or direction on how to implement them. In some cases the deficiency is intentional due to lack of political will; in other cases however, the deficiency is circumstantial due to lack of resources.

This guide is intended to assist regional governments by proposing concrete, specific alternatives to carry out and implement otherwise abstract principles.

In terms of mechanics, scholars and practitioners have identified a number of steps to be taken and questions to be answered before embarking on new legislative initiatives. Questions include those relating to needs assessment, cost-benefit analyses, and feasibility studies on likely implementation and enforcement of new laws. Those questions are often posed in the abstract, and again, few practical applications or example exist that a regional government can use to begin the process. While the central government requires the preparation of a research report in advance of drafting its legislation, the reports are of poor quality and without thorough analysis. In any case, a research report is not required at the regional level. This rough guide suggests a methodology for developing new legislation, including preparation of a research report with appropriate detail and analysis, as well as how to conduct several rounds of public consultation and revision.

This guide also raises two types of legal frameworks for regional governments to consider as alternatives to the typical regulatory law that is heavily prescriptive with onerous requirements, and that enjoys little compliance and little enforcement. The first type is the concept of a framework law, or enabling law, which is a basic law that establishes the legal and institutional framework for management, without specific regulatory prohibitions that likely would not be well planned, and almost certainly would not be properly enforced. For regional governments that do not have any legislation relating to forestry management, this guide recommends this approach. A 'first generation' framework law would establish the legal and institutional framework for resource management, and leave room for subsequent generations of legislation and regulation that could be written as the government gains the resources and enforcement capabilities for implementation. The second type is the concept of voluntary, incentive-based laws. For districts that do not have resources or political will for enforcement, additional laws that impose additional requirements will meet with the same fate as existing laws that are not enforced. This guide suggests that regional governments consider alternative types of laws, such as incentive-based laws. 
The guide is not meant to be an academic treatise on law and governance in the forestry sector. Rather, it is meant to be a practical manual, to raise issues, and propose hands-on practices that can be readily implemented. Its target audience is the local government officials that are struggling with the everyday realities of poor funding, small staffs, limited experience and training, and powerful interests that have historically shaped forestry management. As a result, the guidelines that this manual offers to address problems facing Indonesia's forests may not be the theoretical ideal, and they may not satisfy the academic purist who desires the perfect model of good governance. Instead, this guide proposes workable, albeit imperfect, solutions for regional governments that have a true desire to manage their forests sustainably. 


\section{References}

Aman, Alfred C., and Mayton, William T., 2001. Administrative Law, 2d ed., West Group, St. Paul, MN.

Andreen, William L., 2000. Environmental Law and International Assistance: The Challenge of Strengthening Environmental Law in the Developing World, 25 Columbia Journal of Environmental Law, Vol 25, pp. 17, 27.

Arnstein, Sherry R., 1969. A Ladder of Citizen Participation, Journal of the American Institute of Planners, Vol. 35: 216-224.

Asia Foundation, 2002. First Indonesia Rapid Decentralization Appraisal (IRDA): Synopsis Report, Jakarta.

Asian Development Bank, 2002a. Indigenous Peoples/Ethnic Minorities and Poverty Reduction in Indonesia, Manila.

Asian Development Bank, 2002b. Draft Country Governance Assessment Report: Indonesia. Jakarta.

Axelrod, R.M., 1984. The Evolution of Cooperation. Basic Books, New York, NY.

Barr, Christopher, et al., 2001. The Impacts of Decentralization on Forests and ForestDependent Communities in Kabupaten Malinau, East Kalimantan: Case Study 3 on Decentralisation and Forests in Indonesia, Center for International Forestry Research, Bogor, Indonesia.

Bell, Gary F., 2001. The New Indonesian Laws Relating to Regional Autonomy: Good Intentions, Confusing Laws, Asian-Pacific Law \& Policy Journal, Vol. 2, p. 1.

Bennett, C.P.A., 2001. Village Governance and Decentralisation of Natural Resource Management in Indonesia: Of "Responsibility", Accountability and National Unity. In, Colfer, C.J.P. and Resosudarmo, I.A.P. (eds.) 2002. Which Way Forward? People, Forests, and Policymaking in Indonesia. Resources for the Future (RFF), Washington, D.C.

Blumenthal, Dan and Jannink, Jean-Luc, 2000. A Classification of Collaborative Management Methods, Conservation Ecology 4(2): 13. (www. consecol.org/vol4/iss2/art13).
Borrini-Feyerabend, ed., Beyond Fences: Seeking Social Sustainability in Conservation, IUCN, 1997, p. 14.

Botchway, Francis, 2001. Good Governance: The Old, the New, the Principle, and the Elements, Florida Journal of International Law, Vol 13, pp. 159, 161.

Brown, Timothy H., 1999. Economic Crisis, Fiscal Decentralization and Autonomy: Prospects for Natural Resource Management. Jakarta, published by the Natural Resources Management Project.

Casson, Anne, 2001. Decentralisation of Policies Affecting Forests and Estate Crops in Kotawaringin Timur District, Central Kalimantan: Case Study 5 on Decentralisation and Forests in Indonesia, Center for International Forestry Research, Bogor.

Cicin-Sain, Biliana and Knecht, Robert W., 1998. Integrated Coastal and Ocean Management: Concepts and Practices, Washington, D.C.: Island Press.

CIFOR Long Loreh team, 2001. Team includes: Godwin Limberg, Njau, Ramses, Made, Moira Moeliono, Tony Djogo. Personal communication, 3-25 May.

Dicey, A.V. 1958. Introduction to the Study of the Law of the Consitution Part II.

Donor SMP Working Group, 2002. Local Government Obligatory Functions and Minimum Service Standards: A Proposal for Conceptual Development and Implementation, unpublished draft, June. (The Donor SMP Working Group consists of: United States Agency for International Development, the Deutsche Gesellschaft für Technische Zusammenarbeit, the Canadian International Development Agency, the Japanese International Cooperation Agency, the Australian Agency for International Development, The World Bank, the Asian Development Bank, and the United Nations Development Program).

Estache, Antonio, ed. Decentralizing Infrastructure: Advantages and Limitations, World Bank Discussion Paper 290, Washington D.C., 1995, p. 18 
Fisman, Raymond and Gatti, Roberta, 1999. Decentralization and Corruption: Cross-County and Cross-State Evidence. The World Bank, Washington, D.C.

GTZ (Deutche Gesellschaft fur Technische Zusammenarbeit), 2001. Project Support for Decentralization Measures (SfDM), Decentralization News Issues No. 1-8. Available online: http://www.gtzsfdm.or.id. Aug. 2001.

Gurodaboro, Pak Moses, 2001. Legal Section, Office of the Bupati, District Malinau. Personal communication 26 May.

Hart, H.L.A., 1961. The Concept of Law. Oxford, England: Oxford University Press.

Hofman, Bert and Kaiser, Kai, 2002. The Making of the Big Bang and Its Aftermath: A Political Economy Perspective. Paper presented at Conference "Can Decentralization Help Rebuild Indonesia?” by International Studies Program, Andrew Young School of Policy Studies, Georgia State University. 1-3 May. Atlanta.

Impang, Pak Lungu, 2001. Kepala Desa of Langkap, Malinau. Personal communication, 15 May.

International Tropical Timber Council, 2001. Achieving Sustainable Forest Management in Indonesia: Report Submitted to the ITTC by the Mission Established Pursuant to Decisions 12 (XXIX) 'Strengthening Sustainable Forest Management in Indonesia, 31 $1^{\text {st }}$ Session, 29 Oct.3 Nov., Yokohama, Japan.

Kre, Pak Ipo, 2001. Kepala Adat, personal communication 17 May.

Lindsay, Jonathan M., 2000. Creating Legal Space for Community Based Management: Principles and Dilemmas, in Decentralization and Devolution of Forest Management in Asia and the Pacific, ed. Thomas Enters, Patrick B. Durst and Michael Victor, RECOFTC Report No. 18 and RAP Publication, 2000, Bangkok, Thailand.

Lindsay, Jon, Ali Mekour and Lawrence Christy, 2002. Why Law Matters: Design Principles for Strengthening the Tole of Forestry Legislation in Reducing Illegal Activities and Corrupt Practices, FAO Development Law Service, FAO Legal Papers Online \#27, http://www.fao.org/ Legal/pb-e.htm.

Lynch, Owen J. and Emily Harwell, 2002. Whose Natural Resources? Whose Common Good? Towards a New Paradigm of Environmental Justice and the National Interest in Indonesia, CIEL. Jakarta, p. 142.

Mariasa, Ir. I.G.P., 2001. Pimpinan, PT Inhutani II Sub-Unit Malinau. Malinau Kabupaten, East Kalimantan, Personal communication, May 11.

McCarthy, John F., 2001. Decentralisation, Local Communities and Forest Management in Barito Selatan District, Central Kalimantan: Case Study 1 on Decentralisation and Forests in Indonesia,
Center for International Forestry Research, Bogor, pp. 11-13.

Ministry of Home Affairs, 2002a. Surat Edaran No. 100/756/OTDA tentang Penyusunan Kewenangan Wajib dan Standar Pelayanan Minimal (8 July 2002), addressed to Ministerial (Departemen) and Non-Ministerial (Lembaga Pemerintah Non-Departemen) Secretaries General. http://www.gtzsfdm.or.id/documents/ laws_n_regs/others/SE-8Juli02-SEKTOR\%20SEKDEP-LPND.pdf.

Ministry of Home Affairs, 2002b. Surat Edaran No. 100/757/OTDA tentang Penyusunan Kewenangan Wajib dan Standar Pelayanan Minimal (8 July 2002), addressed to provincial governors, regents, and mayors. http:// www.gtzsfdm.or.id/documents/ laws_n_regs/ others/SE_KWandSPM_Gubernur_Juli2002.pdf.

Ostrom, E. 1992. The rudiments of a theory of the origins, survival and performance of commonproperty institutions. Pp. 293-318 in DW Bromley et al. Eds., Making the commons work: Theory, practice, and policy, ICS Press, Oakland CA.

Patlis, J.M., Dahuri, R., Knight, M. and Tulungen, J., 2001. Integrated Coastal Management in a Decentralized Indonesia: How It Can Work, Jurnal Pesisir \& Kelautan (Indonesian Journal of Coastal and Marine Resources, Vol. 4, No. 1., Bogor, Indonesia.

Patlis, Jason, 2002. Mapping Indonesia's Forest Estate from the Lawyer's Perspective: Laws, Legal Fictions, Illegal Activities, and the Gray Area. Unpublished Preliminary Assessment prepared for The World Bank-World Wildlife Fund Alliance, Jakarta.

Patlis, Jason, Knight, Maurice and Benoit, Jeff, 2003. Integrated Coastal Management in Decentralizing Developing Countries: The General Paradigm, the U.S. Model and the Indonesian Example, The Ocean Yearbook, Vol. 17, U. Chicago Press, Chicago, IL.

Reuben, William, 2003. The Role of Civic Engagement and Social Accountbility in the Governance Equation, Social Development Notes, Note No. 75, The World Bank, Washington, D.C.

Seidman, Ann and Seidman, R.B., 1997. Beyond Contested Elections: the Process of Bill Creation and the Fulfillment of Democracy's Promises to the Third World, Harvard Journal on Legislation, Vol 34, p. 1.

Seidman, Ann, Seidman, R.B. and N. Abeyesekere, 2001. Legislative Drafting for Democratic Social Change: A Manual for Drafters. Boston, Mass.: Kluwer Law International.

Simarmata, Rikardo, 2003. Regional Autonomy and the Character of Local Government Laws and Regulations New Pressures on the Environment 
and Indigenous Communities: A Preliminary Diagnosis , Paper submitted for the International Association for the Study of Common Property 9th Biennial Conference, Victoria Falls, Zimbabwe.

Smith, Scott and Martin, Alejandra, 2000. Achieving Sustainability of Biological Conservation: Report of a GEF Thematic Review. Monitoring and Evaluation Working Paper I. Global Environment Facility.

Tendler, Judith, 1997. Good Government in the Tropics, The Johns Hopkins University Press, Baltimore, p. 146.

Thorburn, Craig Dr., 2002. Community Development Advisor, Bejis Project, AusAID. Personal communication, 23 May.
Pope, Jeremy, 2000. Confronting Corruption: The Elements of a National Integrity System (TI Source Book), Transparency International, Berlin.

Turner, Mark and Hulme, David, 1997. Governance, Administration and Development: Making the State Work. Kumarian Press, West Hartford, CT., p. 122-124.

U.S. Embassy, 1999. Economic Report: Where the (Natural Resource) Wealth Is, May 18.

World Resources Institute, 2002. Closing the Gap: Access to Information, Participation, and Justice in Decision-Making for the Environment. Washington, DC.

\section{Related CIFOR publications}

Case Study 1. McCarthy, J.F. 2001. Decentralisation, local communities and forest management in Barito Selatan District, Central Kalimantan. Center for International Forestry Research, Bogor, Indonesia.

Case Study 2. McCarthy, J.F. 2001. Decentralisation and forest management in Kapuas District, Central Kalimantan. Center for International Forestry Research, Bogor, Indonesia.

Case Study 3. Barr, C., Wollenberg, E., Limberg, G., Anau, N., Iwan, R., Sudana, I.M., Moeliono, M., and Djogo, T. 2001. The Impacts of decentralisation on forests and forest-dependent communities in Malinau District, East Kalimantan. Center for International Forestry Research, Bogor, Indonesia.

Case Study 4. Casson, A. 2001. Decentralisation of policymaking and administration of policies affecting forests and estate crops in Kutai Barat District, East Kalimantan. Center for International Forestry Research, Bogor, Indonesia.

Case Study 5. Casson, A. 2001. Decentralisation of policymaking and administration of policies affecting forests and estate crops in Kotawaringin Timur District. Central Kalimantan. Center for International Forestry Research, Bogor, Indonesia.

Case Studies 6 and 7. Potter, L. and Badcock, S. 2001. The effects of Indonesia's decentralisation on forests and estate crops: Case study of Riau province, the original districts of Kampar and Indragiri Hulu. Center for International Forestry Research, Bogor, Indonesia.

Case Study 8. Soetarto, E., Sitorus, M.T.F. and Napiri, Y. 2001. Decentralisation of administration, policy making and forest management in West Kalimantan. Center for International Forestry Research, Bogor, Indonesia.

Case Study 9. Obidzinski, K. and Barr, C. 2002. The effects of decentralisation on forests and forest Industries in Berau District, East Kalimantan. Center for International Forestry Research, Bogor, Indonesia.

\section{Others}

Anau, N., Iwan, R., van Heist, M., Limberg, G., Sudana, M. and Wollenberg, E. 2002. Negotiating More than Boundaries: Conflict, Power and Agreement Building in the Demarcation of Village Borders in Malinau, 131-156. In: Technical Report Phase I 1997-2001. ITTO Project PD 12/97 Rev.1 (F) Forest, Science and Sustainability: The Bulungan Model Forest. Center for International Forestry Research, Bogor, Indonesia.

Casson, A. and Obidzinski, K. 2002. From New Order to Regional Autonomy: Shifting Dynamics of Illegal Logging in Kalimantan, Indonesia. World Development 30(12):2133-51.

Resosudarmo, I.A.P. 2003. Shifting Power to the Periphery: The Impact of Decentralisation on Forests and Forest People. In: Aspinall, E. and Fealy, G. (eds.) Local Power and Politics in Indonesia: Decentralisation and Democratisation, 230-244. Singapore, Institute of Southeast Asian Studies.

Oka, N.P. and William, D. 2004. The Policy Dilemma for Balancing Reforestation Funds. Decentralisation Brief. No. 1. Center for International Forestry Research, Bogor, Indonesia.

Colfer, C.J.P. and Resosudarmo, I.A.P. (eds). 2002. Which Way Forward: People, Forests and Policymaking in Indonesia. Washington, Resources for the Future. 

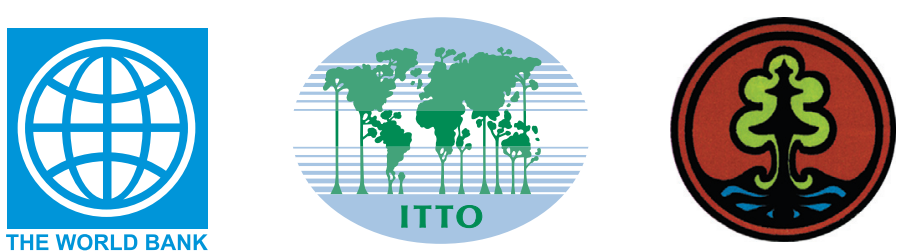

CIFOR's Forests and Governance Programme examines how decisions about forests and forestdependent people are made and implemented in order to promote the participation and empowerment of disadvantaged groups; the accountability and transparency of decision-makers and more powerful groups; and democratic, inclusive processes that support fair representation and decision making among all groups. 